\title{
Law and Theory: Premodern and Contemporary Development of Islamic Discourse on Rebellion
}

\author{
TASHA SOLOMON
}

George Mason University

\begin{abstract}
Scholars have argued that the early theoretical and historical discourses concerning concepts of rebellion and political violence within Islam, specifically Sunni Islam, developed during a time of conflict within the early Islamic Community. In their quest for stability and desire for the preservation of order, early Muslim jurists used key moments in the history of the early Community, as well as doctrinal sources, in order to construct a theoretical discourse addressing rebellion and obedience to authority. Similar to the methods of the early jurists, the construction of contemporary discourses concerning obedience and rebellion have been used by modern Islamic scholars in order to confront issues involving protesting and political violence, especially as they relate to contemporary events such as socio-political movements, dissent, and notably, the Arab Uprisings. The purpose of this paper is to provide a survey of these premodern and contemporary discourses and a description of how their contexts influence Islamic legal approaches.
\end{abstract}

\section{Introduction}

Historical discourse on Islamic law of rebellion developed during a time in which conflict had begun to occur within the early Islamic community after the death of the Prophet Muhammad. According to historians and Islamic scholars, the preservation of order and a desire to keep the community intact were the primary goals of premodern Muslim jurists. In their quest for stability and their insistence on a rule of law, distinctions were drawn on how to address issues of rebellion and obedience. Depending on which school of thought the jurists or scholars belonged to, similar or differing juristic discourses would emerge on how to address these issues, and like all Muslim jurists and legal scholars, their judgments would have stemmed from the doctrinal sources: Hadith, Sunnah of the Prophet, or the Quran. 
This paper is a survey of premodern-roughly considered to be between the $9^{\text {th }}$ and $18^{\text {th }}$ centuries (Nakissa 399) - and contemporary discourse on rebellion and political violence, divided into three sections. The first section is devoted to examples from the doctrinal sources mentioned above in order to provide a textual reference point for many of the themes mentioned throughout this paper, particularly the ideas related to the preservation of order, obedience, and authority. It is not the purpose of this paper to question the authenticity of these doctrinal sources or their transmissions, but, using textual analysis, to explore how these texts have been utilized over time in the crafting of Islamic discourse. Using Khaled Abou el Fadl's examination of political resistance and rebellion in Islamic jurisprudence, Rebellion and Violence in Islamic Law, as a main source and reference point, the second portion of the paper documents the emergence of Islamic discourse on rebellion, called ahkam al-bughah, and the varying interpretations of the discourse by prominent early Muslim jurists. This paper focuses on Sunni jurisprudence, however, a separate analysis concerning the varying sects of Islam on this topic would be highly beneficial for any future research. Finally, the third portion focuses on contemporary discourses concerning protesting, political violence, and obedience to authority figures, with specific focus on differences in contemporary juridical views on the Arab Uprisings. As it is shown in this section, ahkam al-bughah has been maintained as an early discourse concerning rebellion; however, given contemporary interpretations of issues concerning dissent and political violence, there have been efforts by many scholars to either address these issues using the doctrinal sources or to establish newer legal subfields through which to theorize.

\section{The Quran, Sunnah of the Prophet, and the Hadith: Doctrinal Sources}

Throughout readings of the Quran, exploration of the Sunnah (the practices of the Prophet), as well as the Hadith (reports attributed to the Prophet), classical Sunni tradition is clear that rebellion should not be allowed, even if it is against an unjust ruler. In the Quran, for example, there are verses that explicitly instruct Muslims to obey those whom God has designated as figures of authority. Surah 4 of the Quran, titled "Al Nisa" (Women), not only references matters concerning property, lineage, heritage, and marriage, but also includes verses that address war practices and conflict between the Islamic Community in Medina and others outside of the Muslim Community, specifically Christians and Jews. For example, in Surah 4:59 
Muhammad revealed the following verse: "You who believe, obey God and the Messenger, and those in authority among you. If you are in dispute over any matter, refer it to God and the Messenger, if you truly believe in God and the Last Day: that is better and fairer in the end." In this verse, God not only commands believers to obey those in authority, but also makes this an obligation of faith.

According to the English translation of 'Ali ibn Ahmad al-Wahidi's Asbad al-Nuzul, which details the occasions, reasons, and contexts of Quranic revelations, verse 4:59 was revealed following a dispute between Khalid ibn al-Walid, tasked by the Prophet to execute a military expedition to one of the Arab clans, and 'Ammar ibn Yasir, a former slave who accompanied Khalid. According to this particular tradition, as well as the matn, or text, of the accompanying hadith, as Khalid and his group approached an Arab clan, he decided to rest for the night before conquering the camp the following morning; however, during this time the entire clan, except for one man, became aware of Khalid and the expedition, and decided to flee. The man, a Muslim, went to 'Ammar and said: "O Abu'l Yaqzan (the final nasab, or patronymic of 'Ammar's name)! I am one of you. But my people ran away when they heard you were coming. I stayed because I am a Muslim. Is this of any benefit to me, or shall I flee as my people did?" (Wahidi 54). To summarize the following events that took place: 'Ammar instructed the man to stay, believing that because he was Muslim it would be beneficial for him not to flee because he would be treated kindly. However, when Khalid invaded the clan and found that the man was the only person left, he arrested him and seized his property. A dispute erupted between 'Ammar and Khalid when Khalid became angry after hearing that "Ammar had already given the man amnesty. A shouting match ensued, in which Khalid stated, "You give protection from me to others while I am the leader!" (Wahidi 55). This caused them both to enlist the guidance of the Prophet who, in the end, not only approved the amnesty given by 'Ammar to the man, but he forbade "Ammar from giving amnesty to anyone in the future without the permission of his leader. The Prophet, however, did not stop there. After the two continued hurling insults at one another, Khalid, very much aware of his leadership role over 'Ammar, spoke to the fact that 'Ammar is a former slave and therefore questioned how the Prophet would allow him the ability to speak to an authority figure as he did. The Prophet replied: "O Khalid, leave 'Ammar alone, for whoever insults 'Ammar, Allah will insult him, and whoever hates 'Ammar, Allah will hate him" (Wahidi 55). After this, according to the hadith tradition, Khalid then went and asked 
'Ammar for forgiveness. God, pleased with what had just resulted from the disagreement between these two, then revealed verse 4:59 to Muhammad, commanding obedience toward those in authority.

The text of verse 4:59, although it does not provide much detail, does fall in line with the overall theme that prohibits fighting and civil strife (fitna) within the Muslim community. The occasion of the revelation seems to illustrate Muhammad's desire to appease his Companions in hopes of preventing any intra-community strife. In addition to the surah mentioned, there are many other Sunni hadith that speak to the nature of Muhammad and the Companions to prevent or quell rebellion and violence against one another. Examples of these hadith can be found in Kutub al-Sittah (Six Books), which are the six major hadith collections by Sunni Muslim scholars, sometimes referred to as "The Authentic Six." Two of the scholars who authored collections in Kutub al-Sittah are Muhammad ibn Ismail al-Bukhari and Abu Dawud Sulayman ibn al-Ash'ath al-Azdi al Sijistani.

Sahih al-Bukhari, the collection of Muhammad al-Bukhari, one of the most notable Sunni Islamic scholars, is considered by Sunnis and some Shia, such as the Zaidi, as one of the most authentic hadith collections. Found throughout the text are verses that speak in some form or another about situations concerning rebellion, obedience, and how believers should address issues with a ruler, be he just or unjust. In order to illustrate this, the next passage features excerpts from a translation of Sahih al-Bukhari, Book 88, called "Afflictions and the End of the World," concerning the consequences of rebellion. In Volume 9, Book 88, Hadith 176, is a narration by Ibn Abbas which reads: "The Prophet said, 'Whoever disapproves of something done by his ruler then he should be patient, for whoever disobeys the ruler even a little [little $=\mathrm{a}$ span] will die as those who died in the Pre-Islamic Period of Ignorance [i.e. as rebellious Sinners]" (Sunnah and Hadith).

Volume 9, Book 88, Hadith 178, narrated by Junada bin Abi Umaiya, provides an another example of hadith often used to promote obedience to authority:

We entered upon 'Ubada bin As-Samit while he was sick. We said, 'May Allah make you healthy. Will you tell us a hadith you heard from the Prophet and by which Allah may make you benefit?' He said, 'The Prophet called us and we gave him the Pledge of 
allegiance for Islam, and among the conditions on which he took the Pledge from us, was that we were to listen and obey (the orders) both at the time when we were active and at the time when we were tired, and at our difficult time and at our ease and to be obedient to the ruler and give him his right even if he did not give us our right, and not to fight against him unless we noticed him having open $K u f r$ (disbelief) for which we would have a proof with us from Allah. (Sunnah and Hadith)

Similar to the previous hadith example, this hadith illustrates that showing patience and obedience to authority are conditions of faith for believers. It also ensures that believers understand that even if there is cause to believe that a ruler is unjust through the practice of $K u f r$ (disbelief), only God is capable of making such a determination.

Outside of the translation of Bukhari, one can also find hadith where there are verses that explicitly instruct Muslims to obey their rulers, even during times of oppression. For example, in Abu Dawud's Sunan Abu Dawud's Book 35 titled "Trials and Fierce Battles" (or by its Arabic title, Kitab al-Fitan Wa Malahim), in Hadith 4232, there is a line that reads that the Prophet once said, "If Allah has on Earth a caliph who flays your back and takes your property, obey him, otherwise die holding onto the stump of a tree" (Sunnah and Hadith). Sunan Abu Dawud also includes hadith that preach avoidance of dissent and of speaking ill. In Book 35, Hadith 4250, it has been narrated that Muhammad once said the following: "The happy man is he who avoids dissensions; happy is the man who avoids dissensions: but how fine is the man who is afflicted and shows endurance" (Sunnah and Hadith), as well as: "There will be civil strife (fitna) which will render people deaf, dumb and blind regarding what is right. Those who contemplate it will be drawn by it, and giving rein to the tongue during it will be like smiting with the sword" (Sunnah and Hadith). In Book 37, Hadith 4330, of Sunan Abu Dawud, titled "Battles" (Kitab alMalahim), the Prophet is said to have announced, "The best fighting (jihad) in the path of Allah is (to speak) a word of justice to an oppressive ruler." Written in the two previously mentioned Sunan Abu-Dawud hadith, it can be interpreted that God, through Muhammad, is making it clear that during times of fitna, whether against one another or against an oppressive ruler, it is best to remove oneself from a hostile situation. In addition, it warns of the dangers of using harmful words, with the intention of preventing further disagreement and conflict. However, if fighting (jihad) must occur, let the "weapon" of choice be one's words of righteousness. 
Given the content of the previously mentioned Quranic verses and hadith, it could be assumed that, like these verses, the premodern Muslim jurists were staunch opponents of rebellion and dissent, but as Khaled Abou el Fadl asserted, direct adherence to the traditional text was not necessarily the primary objective. If that were the case, it would have been difficult for the early jurists to establish jurisprudence that declared rebellion to be a criminal act without acknowledging, or subsequently suggesting, that many of the Prophet's Companions were criminals. According to Abou el Fadl, this is where the jurists "literally invented the field of ahkam al-bughah [juristic discourses on rebellion] by reconstructing and emphasizing certain theological precedents and deemphasizing others" (22). Most importantly, he stated, "Muslim jurists affirmed a general legal principle: those in power must be obeyed. But they went on to riddle the field with qualifications, exceptions, and provisos so as to render the general principles quite complicated, and to elicit the classic legal response to many legal issues - 'It depends"” (22).

As will be discussed later, the jurists did not see the discursive development of ahkam albughah as one that directly opposed the traditions of the faith, but one that could establish or reestablish order while minimizing disorder. In fact, there were some jurists who believed that the fighting between the Companions was deliberate in order to "teach Muslims ahkam albughah" (Abou el Fadl 33). The civil wars between the Companions of the Prophet were used as a reference point in order to facilitate a need by the early jurists to amalgamate history and politics with theology. This further allowed them to establish criteria for various forms of dissent, and from there they "co-opted, constructed, and reconstructed doctrinal and historical precedents" in order to build their discourse (Abou el Fadl 33).

\section{Early Juridical Discourses}

In 2001, Khaled Abou el Fadl published his work, Rebellion and Violence in Islamic Law, detailing the emergence and development of discourse on rebellion and violence within Islamic law, primarily focusing on premodern Muslim jurists. Perhaps at the heart of the discourse on rebellion is the Islamic belief that, although God is the ultimate ruler, there are also human beings through which God's will is to be carried out. As Abou el Fadl pointed out: "From an institutional and social point of view, God's will could be represented by a variety of political or social realities... From a doctrinal and, perhaps, dogmatic, perspective, God's will is 
represented primarily by the ruler and the jurists who are considered God's special agents on earth" (1). A major factor of the argument on rebellion within early Islamic discourse are issues of authority and legitimacy. If there is a person who has been chosen by God to rule over His people, that person and their rule are, theologically and politically speaking, legitimateprovided they properly adhere to the Islamic duties passed down by God. The qualifications and duties of a legitimate ruler (caliph) consisted of the application of a contract ('aqd) between the caliph and the community of Muslims, an oath of loyalty or allegiance (bay'a) to the ruler by the community, and a commitment by the ruler to be just and pious through enforcement of the Sharia'a (Islamic law). Issues concerning authority and legitimacy were important when the focus was placed on those who wished to rebel or defy the ruler. Premodern discourse made a distinction between those who wish to rebel because the ruler is not properly adhering to his duties, and those who seek to cause strife and mayhem (fitna). As mentioned previously, the early Muslim jurists established the ahkam al-bughah as an attempt to establish and/or maintain order within the Islamic community, but this does not mean that the early jurists were always quietists, as one could reasonably assume, because there is an absence of the right to rebel in Sunni Islamic tradition and legal discourse. As previously mentioned, however, similar to in modern jurisprudence and discourse, these early legal thinkers adapted to the historical and political contexts of their times. Instead of being open to usurpation if the ruler was not considered "just," and given the change in the structure of the umma (the Muslim community) as Islam continued to spread outside Arabia, jurists restructured their discourses in order to disapprove of and, hopefully, diminish rebellion. According to Abou el Fadl, events in the early history of Islam, such as the revolt and anarchy of the Khawarij, the two civil wars, and the constant rebellions in the first two centuries, "pressured Muslim jurists to emphasize the duty of obedience to the ruler, whether just or unjust, and to engage in endless polemics about the evils of rebellion and anarchy" (9).

An important example, and factor, in how jurists combined the historical, political, and theological is mentioned in the following passage by Abou el Fadl as he references historian Hamilton Alexander Rosskeen Gibb:

The power and influence of the 'Abbasid caliphate steadily decreased throughout the third/ninth century. By the fifth/eleventh century, it had been reduced to virtual impotence...the first 
theoretical and systematic compromise was a pious invention by the Shafi'I jurist al-Mawardi (d. 450/1058) as he attempted to defend the caliphate against the Buwayhid warlords and the Fatimids ruling Cairo. Under certain conditions, al-Mawardi recognized the legitimacy of usurpation as a means of coming to power in the provinces. Al-Mawardi argued that the usurper, by pledging allegiance to the caliph and complying with certain conditions, became the caliph's agent. Effectively al-Mawardi had created a legal fiction of sorts: under certain circumstances a usurper could become the caliph's agent even if the caliph's agent had no real power to restrain or direct his agent...al-Mawardi had opened the door for the eventual supremacy of political expediency over legal order. (9)

In the preceding quote, Gibb explained that as the primary focus for jurists became centered on power rather than any lasting moral imperatives, juristic discourse concerning rebellion developed to address current political situations. After the death of al-Mawardi, commentaries from other jurists such as Shafi'I jurist Abu Hamid al-Ghazali $\left(6^{\text {th }} / 12^{\text {th }}\right.$ century) and Syrian Shafi'I jurist Ibn Jama'a ( $8^{\text {th }} / 14^{\text {th }}$ century) would illustrate the acceptance of a political realism that would demand absolute obedience to unjust rulers and therefore forbid rebellions. However, it would be inaccurate to assert that this was the consensus of all of the early Muslim jurists. There were some, such as Abu Hayyan $\left(8^{\text {th }} / 14^{\text {th }}\right.$ century), who argued that force was acceptable if it was used against an unjust ruler. Abu 'Abd Allah al-Halimi ( $5^{\text {th }} / 11^{\text {th }}$ century), however, argued against the legitimacy of the usurper and in favor of the legitimacy of a ruler who came into power by proper, legal means (i.e., by aqd and bay'a). According to Gibb, however, the majority of jurists during this time would begin to not only sanction the authority of those who usurped power, but also demand that obedience to them would be a moral, legal, and religious obligation: "Thus, according to Gibb, the belief was fostered that 'rebellion is the most heinous of crimes, and this doctrine came to be consecrated in the juristic maxim, 'Sixty years of tyranny are better than an hour of civil strife"” (Abou el Fadl 10).

As mentioned earlier, it has been argued by Abou el Fadl that, in order to construct their discourse on rebellion, Muslim jurists co-opted, constructed, and reconstructed doctrinal and historical precedents. There are two main doctrinal sources cited for the law of rebellion within Islam: 'Ali ibn Abi Talib, the $4^{\text {th }}$ Caliph, cousin, and son-in-law of the Prophet, and the Quran (Abou el Fadl 32). 'Ali's decisions to not attack rebels unless they attacked first; sparing the property and lives of the wounded, fugitives, and prisoners; his refusal to take women and 
children as captives; and pardoning his captives resulted in him being considered the example of how Muslims should treat each other when there is intra-community contention. However, it should also be noted that the actions of other Companions, such as A'isha, Uthman, were either excluded or not cited by the early jurists in their process for the selection of legal precedent. One could argue that this was done for many reasons. The most obvious being that incidents of the Companions acting in "rebellious" ways could further be used as examples for those advocating rebellion and, if, as the jurists would later determine, such acts were detrimental to the community, it would be difficult to justify the "rebellious" actions of the Companions, who are often perceived as being "pure in heart, pure in mind, pure in understanding" (Qutb 17).

Besides 'Ali, the other doctrinal sources used by the early jurists included Quranic verses - examples of which were mentioned earlier - the Sunnah, and Hadith. However, according to Abou el Fadl, there were two main verses jurists utilized during the construction of the discourse. These verses, however, only indirectly address rebellion, as is the case with their asbab al-nuzul (occasion of the revelations). The first verse is known as the baghy verse, in which the word bagha is used in a manner that denotes those who transgress, oppress, or commit injustice. The Quranic verse reads as follows:

If two groups of the believers fight, you [believers] should try to reconcile them; if one of them oppresses the other, fight the oppressors until they submit to God's command, then make a just and even-handed reconciliation between the two of them: God loves those who are even-handed. The believers are brothers, so make peace between your two brothers and be mindful of God, so that you may be given mercy. (Quran 49: 9-10)

Abou el Fadl argued that the above verse seems to address conflict between only two groups, presumably those equal in power, rather than a conflict between a presumed authority figure, or government, and subject(s).

The second verse used by premodern jurists in the construction of the discourse on rebellion is known as the hiraba verse, or ayat al-hiraba, and comes from Surah 5 of the Quran, known as "The Feast." According to this verse:

Those who wage war against God and His Messenger and strive to spread corruption in the land should be punished by death, crucifixion, the amputation of an alternate hand and foot, or 
banishment from the land: a disgrace for them in this world, and then a terrible punishment in the Hereafter, unless they repent before you overpower them - in that case bear in mind that God is forgiving and merciful. (Quran 5:33-34)

The hiraba verse was used to construct discourse around how to address those who commit acts of robbery and banditry, and who wish to cause corruption on earth. As Abou el Fadl denotes, corruption is directly addressed within the Quran and even associated with fitna: "The disbelievers support one another. If you do not do the same, there will be persecution in the land and great corruption" (Quran 8:73).

Akin to the contradictory nature of the occasions of the revelations of ayat al-baghy, and overlooking the actions of some Companions over others, ayat al-hiraba also contains ambiguity, especially when constructing legal discourse. Various debates amongst Muslim scholars on how to interpret the differing reports on the actions of some of the Companions, and the Prophet as well, illustrated that the intended subject of the verse was a contestable issue for the early jurists (Abou el Fadl 49). Nonetheless, both ayat al-baghy and ayat al-hiraba were used by early jurists in order to establish two categories of discourse, one which addressed rebellion and one which addressed bandits. However, as Abou el Fadl asserted,

The historicity, or lack thereof, of these reports is not the point. The point is that these reports provide clues as to how a verse that could possibly have been revealed to address a domestic dispute or a street brawl became co-opted and reconstructed to serve as the basis for juristic discourse on rebellion. Early Muslims saw a connection or nexus between the verse and the tribulations plaguing the Companions. (43)

While attempting to understand the jurists' use of hiraba and baghy, according to Sabia Tabassum, it is as important to understand the distinguishing features of banditry and rebellion, which, without careful examination, appear to be somewhat analogous. Both situations involve a group of people acting in defiance of the "law of the land" or established government; however, they were treated, and, as mentioned earlier, in most cases were punished quite differently. This signified a difference in approach by jurists concerning the actions of those involved in conflict within the community. Hiraba was considered a crime and the criminal law of the land is applied to those who participate (muharibin), while baghy (bughah) was governed by the law of war and those involved were dealt with as combatants. As Tasbassum notes: 
The litmus test for determining the existence of baghy and for distinguishing it from hiraba is whether or not those taking up arms against the government challenges the legitimacy of the government or the system. While muharibin do not deny the legitimacy of the government or the system, bughah consider themselves to be the upholders of justice and claim that they are striving to replace the existing illegitimate and unjust system with a legitimate and just order. In technical terms, it is said that the bughah have ta'wil (legal justification for their struggle). (6)

Jurist and Islamic scholars throughout history have used knowledge gained from the textual precedents set by many doctrinal sources, as well as the varying judgments from those scholars who came before, in their arguments for constructing Islamic legal discourse. As stated earlier, the early jurists were primarily concerned with the need for stability and maintenance of order. It became central to the discourse on rebellion that "Where oppression exists, it must be endured patiently" (Nakissa 399). Anarchy, bloodshed, and civil war were seen as results of revolting, therefore leading to social conflict within the community. However, according to Aria Nakissa, this classical trend in Muslim legal theory has not been consistent among religious scholars throughout the course of Islamic political theory. As Nakissa asserted, contemporary trends within Islamic legal thought, for example through the process of "secondary segmentation," have resulted in "new legal subfields created for the purpose of justifying and regimenting the use of utilitarian modes of juristic reasoning" (398).

\section{Contemporary Discourse and the Arab Uprisings}

The Arab Uprisings that began in late 2010 are perhaps the most quintessential contemporary case for the study of the application of an Islamic law of rebellion or dissent. The mass demonstrations that either occurred or were attempted throughout the Arab world suggested that large portions of the citizenry within these countries had reached a boiling point as to how much they could continue to endure under their repressive regimes. It has been explored throughout this paper that the doctrinal sources - the Quran, Sunnah, and Hadith - have been rather explicit in their desire to prevent rebellion and dissent within the Muslim community. However, given the contemporary political and geographic structure of the Muslim community, modern Islamic scholars continue to address rebellion and dissent using religious justification for their oppositions and approvals. 
In his article "Muslim Discourse on Rebellion," John Kelsay explained that by the $18^{\text {th }}$ century, the political landscape of Islamic territories had begun to change, and the imperial structure had begun to diminish and would, within two centuries, disappear. "Old ways of thinking" that address akham al-bughah, he argued, have primarily fallen into the realm of scholarly research. Within a contemporary framework, "people began to utilize other terms when they wanted to describe a movement directed at opposing an existing regime, such as alintifada ('awakening'), al-inqilab ('overthrow,' 'reversal'), al-thawra ('revolution'), or simply al-jihad ('armed struggle')" (Kelsay 386). Within a contemporary Muslim discursive context, one rarely finds invocation of bughah. This is essentially because individuals and groups such as Osama bin Laden (al-Qaeda), Abu Bakr al-Baghdadi (Islamic State of Iraq and the Levant, or ISIL), and the Taliban, do not perceive themselves as rebels or bandits. Instead, they are mujahiddin, "strugglers" for God's plan. One reason for this, Kelsay argued, is that in order for one to consider themselves bughat, it would require some form of acknowledgment of the legitimacy of an existing government, which in fact is what groups like al-Qaeda, the Taliban, and ISIL proudly promulgate as part of the justification for their acts of violence-their repudiation of their targets' governments and rules of law.

Similar to Kelsay's article, Aria Nakissa wrote in "The Fiqh of Revolution and the Arab Spring: Secondary Segmentation as a Trend in Islamic Legal Doctrine," that the reluctance to utilize arguments of ayat al-bughah has resulted in the establishment of new legal subfields, such as "Fiqh of Revolution" (FR). As mentioned earlier, the Arab Uprisings illustrated a convergence of political and theological perspectives on how to address events throughout the contemporary Arab and Muslim world. Pre-modern jurists used political, historical, and theological perspectives in order to construct the early discourses on rebellion, and the same appears to be the case in the modern era. The difference, however, is that the consensus among scholars, such as Abou el Fadl and others mentioned throughout this paper, is that the early jurists were primarily concerned with the maintenance of stability within the community in order to prevent the continuation of the fitna that caused the civil wars, rebellions, and anarchy of groups such as the Khawarij. According to Nakissa, however, FR represents a continuation of a distinct liberal trend that is, unlike the classical scholars who focus on armed revolt, primarily concerned with peaceful protests. The concept of FR is relatively new, Nakissa asserted, and has therefore received very little scholarly attention. Introduced by the controversial Islamic scholar, Yusuf al- 
Qaradawi, chairman of the International Union of Muslim Scholars (IUMS), FR embodies what he referred to as the "process of secondary segmentation, whereby new legal subfields are created for the purpose of justifying and regimenting the use of utilitarian modes of juristic reasoning" (Nakissa 398).

In the wake of the Arab Uprisings, differing approaches from Islamic scholars and clerics have resulted in both scholarly opposition to and support for the act of protesting within the context of Islamic politics and theology. Prior to the Arab Uprisings, however, the majority of the most respected Salafi authorities denied the religious legitimacy of peaceful protests, stating that it would be best if Muslims addressed their respective authorities in less aggressive ways, such as meeting and dialoging with them in order to reach a compromise. If the authority did not oblige for any reason, Muslims should emulate the actions of the Prophet and endure patiently. Similar to the early jurists, the changing views of contemporary Islamic scholars would become apparent, not only in the context of the fatwas (Islamic religious rulings) issued by certain clerics, but also in the way certain countries, most notably Saudi Arabia, addressed issues of dissent and peaceful protest. Once the Uprisings began and spread throughout the region, "The general Salafi consensus against protests began to disintegrate. Some Salafis embraced the protests, others criticized them, while still others remained undecided" (Nakissa 408). Some clerics, such as Saudi scholar Rabi' bin Hadi al-Madkhali, asserted that the protests and marches were "products of a disbelieving West," and that what would emerge was "the worst and most dangerous forms of fitna that have struck the Muslim community," and, citing the Hadith, commanded that the authority of a ruler, be he just or unjust—or even if he prohibits peaceful protests - must be obeyed (Nakissa 408). In his argument, such obedience to the ruler wards off fitna, and "despite claims to the contrary, peaceful protests inevitably engender violent fitna. He observes that Libyan Arab Spring protests evolved into bloody armed insurrection. Meanwhile, clashes between police and protestors in Egypt and Tunisia resulted in grave loss of life and destruction of property" (Nakissa 408). Interestingly, al-Madkhali also admitted that Muslim rulers are not exempt from error and injustice; however, he stated that it is not the duty of the common people to address these discrepancies - only those learned in Islamic scholasticism could meet with and address these issues with the ruler. 
Some scholars, such as Egyptian hadith scholar Abu Ishaq al-Huwayni, provided support for the protests of the Arab Uprisings. Instead of arguing against or providing a different interpretation of the doctrinal sources, these scholars declared that, due to the "absence of a 'definitive text' banning protests," before ruling against the legitimacy of protesting, there would need to be an examination of whether the harm of protesting outweighed the benefits (Nakissa 412). However, for those scholars who seek to theorize a new field of juristic study (neither Huwayni nor Madkhali do), FR is used to address the issue of protests using principles of legal theory, rather than specific doctrinal sources. For example, because there are no scriptural references prohibiting protesting, like any other act not explicitly prohibited, it is allowed unless there is an existing doctrinal source stating otherwise.

\section{Conclusion}

The Quran, Hadith, and Sunnah, are quite clear that God, through the Prophet Muhammad, commands obedience to rulers and authority figures, even if they are unjust. This, as it is specifically mentioned within the doctrinal texts, is believed by many Sunni Muslims to be an effort at preventing fitna, or civil strife, within the Community and on earth. The historic, premodern discourses referring to rebellion, ahkam al-bughah, were created in an effort to maintain order within the Muslim community, in fear of a continuation of disorder and conflict after the death of the Prophet. These discourses used the doctrinal sources in order to establish juridical frameworks that would combine the historical, political, and theological contexts of their times in the hope of stability and order. Ahkam al-bughah has been used as an orderpreserving discourse, and according to John Kelsay, "one understands why few people want to invoke it in the current setting. We are in a moment in which Muslim argument about armed force is dominated by those who want to change the status quo, so that the preference for jihad is connected with its order-transforming possibilities" (388).

Within a contemporary context, however, the premodern views of the early jurists began to change as events such as the Arab Uprisings and the countless other social movements before it challenged the established juristic discourses on how Muslims should address issues of modernization, democracy, human rights, oppression, and peaceful protests. As explained by John Kelsay, "The Arab Spring and its aftermath thus continue the trend of modern Islamic 
political discourse. The vocabulary of ahkam al-bughah is not much in use. It may simply be that it was crafted for a time when the assignment of legitimate rule seemed clearer than at present" (390). It should be noted that relatively modern concepts, such as secularization and globalization, will likely play a role in the way that politics and theology are continuously utilized within Muslim-majority countries. It has also been quite evident that, just as these discursive views changed throughout premodern times, given the geopolitical state of the international community, issues such as rebellion, dissent, protest, and political violence will continue to generate new legal fields and discourses on how to address these, and similar, issues. 


\section{Works Cited}

Abou el Fadl, Khaled. Rebellion and Violence in Islamic Law. Cambridge: Cambridge University Press, 1996. Print.

Kelsay, John. "Muslim Discourse on Rebellion.” Ethics \& International Affairs 27.4 (201): 379391. Web. 11 Dec. 2015.

Nakissa, Aria. "The Fiqh of Revolution and the Arab Spring: Secondary Segmentation as a Trend in Islamic Legal Doctrine Fiqh of Revolution.” The Muslim World 105:3 (2015): 398 - 421. Web. 11 Nov. 2015.

The Qur'an. Trans. by M. A. S. Abdel Haleem. New York: Oxford University Press, 2005. Print.

Quṭb, Sayyid. Milestones. Indianapolis: American Trust, 1990. Print.

Sunnah and Hadith. University of Southern California Center for Muslim-Jewish Engagement, n.d. Web. 14 Dec. 2015.

Tabassum, Sadia. "Combatants, Not Bandits: The Status of Rebels in Islamic Law." International Review of the Red Cross 93 (2011): 121-139. Web. 11 Nov. 2015.

al Wahidi, Ali ibn Ahmad. Asbab al-Nuzul. Trans. Mokrane Guezzou. Amman: Royal Aal alBayt Institute for Islamic Thought, 2008. Web. 12 Dec. 2015. 